\title{
ZRÓŻNICOWANIE PRZESTRZENNE ZACHOWAŃ WYBORCZYCH MIESZKAŃCÓW GMINY SZADEK W WYBORACH PREZYDENCKICH I PARLAMENTARNYCH W 2015 ROKU
}

Streszczenie. Artykuł prezentuje zachowania wyborcze mieszkańców gminy Szadek w wyborach z 2015 r. na prezydenta RP oraz do sejmu i senatu. W ramach zachowań wyborczych przedstawiono frekwencję wyborczą oraz wyniki głosowań w rozbiciu w każdym z obwodów wyborczych oraz w ujęciu syntetycznym miasto-wieś. W artykule została podjęta próba wyjaśnienia zróżnicowania frekwencji wyborczej oraz przesunięć wewnątrz elektoratów.

Slowa kluczowe: Szadek, wybory prezydenckie, wybory parlamentarne, zachowania wyborcze.

Na polskiej scenie politycznej po 1989 r. wyklarowały się podziały na prawicę i lewicę (sytuujące się wzdłuż osi wartości) oraz liberałów i ludowców (sytuujące się wzdłuż antagonizmu interesów). W literaturze przedmiotu zauważa się, że geografię wyborczą naszego kraju niezmiennie determinują czynniki, które można ulokować na wspomnianych wyżej dwuwymiarowych płaszczyznach ${ }^{1}$. Pierwszy wymiar stawia na jednym końcu ,prawicę”, a na drugim „lewicę” i nazywany jest osią wartości. Rozkład przestrzenny tych dwóch elektoratów wynika w dużej mierze z granic historycznych, a konkretnie stanowi konsekwencję okresu, kiedy Polska znajdowała się pod zaborami. Podział kraju doprowadził do zróżnicowania odseparowanych od siebie obszarów zarówno pod względem społeczno-ekonomicznym, jak i światopoglądowym. Najsilniejsze poparcie dla ,prawicy” obserwuje się głównie na obszarach dawnej Galicji oraz we wschodniej części Królestwa Kongresowego (w tym Polaków zamieszkujących na obszarze współczesnej

* Michał Kowalski, mgr, asystent, Katedra Zagospodarowania Środowiska i Polityki Przestrzennej, Wydział Nauk Geograficznych, Uniwersytet Łódzki.

1 T. Zarycki, Kulturowe-polityczne uwarunkowania modernizacji Polski wschodniej i zachodniej. Geografia polityczna i jej interpretacje, [w:] Historyczno-kulturowe uwarunkowania rozwoju: Polska i Ukraina, red. G. Gorzelak, A. Tucholska, Warszawa 2008, s. 59. 
Litwy $^{2}$ ), a także na Kaszubach i Podlasiu. Najsilniejsze poparcie dla lewicy notuje się natomiast przede wszystkim na: Pomorzu Zachodnim, Warmii i Mazurach, zachodniej części dawnego Królestwa Kongresowego oraz na obszarach zamieszkiwanych przez mniejszości narodowe. Drugi wymiar, nazywany osią interesów (przeciwstawienie liberałów i ludowców) dotyczy podziału na miasto i wieś. Jest on tłumaczony odmienną sytuacją (ekonomiczną i strukturą zawodową) elektoratu miejskiego i wiejskiego. W tym przypadku można przeciwstawić aglomeracje łódzką, warszawską czy śląską z gminami zlokalizowanymi na obszarze dawnych ziem zaboru rosyjskiego ${ }^{3}$.

Od wyborów prezydenckich i parlamentarnych w 2005 r. na pierwszy plan wysunął się trwający do dziś spór pomiędzy Platformą Obywatelską (obozem liberalnym) a prawicą (zdominowaną przez Prawo i Sprawiedliwość). Od tego czasu, kolejne wybory utrwalały ten podział (za wyjątkiem wyborów samorządowych w 2014 r., gdzie obok dwóch powyższych ugrupowań znaczną część wyborców przyciągnęło Polskie Stronnictwo Ludowe). W ostatnich latach programy polskich partii politycznych w coraz większym stopniu zaczęły odbiegać od klasycznego (wcześniej przedstawionego) podziału. I tak w partiach prawicowych (a w zasadzie największej partii prawicowej - PiS) pojawił się coraz większy udział postulatów realizujących osie interesu (socjalne podejście do gospodarki), zaś w największej partii liberalnej w debacie publicznej rosło znaczenie postulatów wartości - co do zasady chrześcijańsko-demokratycznych - a w społecznym odbiorze centrowych i centrowo-lewicowych. Jest to efektem tego, że partie starają się tak sformułować swoją ofertę wyborczą, aby przekonać do siebie jak najwięcej potencjalnych wyborców.

Przedstawiany tekst ma na celu zobrazowanie wyników ogólnokrajowych wyborów (prezydenckich oraz do sejmu i senatu) w ujęciu lokalnym - gminy miejsko-wiejskiej Szadek. Poddanie analizie tego właśnie obszaru wydaje się szczególnie interesujące z dwóch powodów. Po pierwsze lokalizowany jest on „na granicy” pomiędzy tą częścią Polski, która skupia ośrodki poparcia opcji „prawicowych”, oraz tą, która jest bardziej zorientowana „lewicowo” (a w ostatnim czasie liberalnie). Po drugie jest on podzielony na dwie części - miejską i wiejską, w których z reguły daje się zaobserwować polaryzacja sceny politycznej względem osi interesów.

\section{METODY BADAŃ}

Analizy dokonywane w niniejszym artykule oparte są o frekwencje wyborcze i wyniki wyborów prezydenckich (dwóch tur) i parlamentarnych w gminie Szadek. Zostały one podane do publicznej wiadomości przez Państwową Komisję

${ }^{2}$ M. Barwiński, K. Leśniewska, The comparison of the contemporary situation of national minorities in Poland and Lithuania, Geografijos metraštis, t. 46, Wilno 2013, s. 56-58.

${ }^{3}$ M. Kowalski Polaryzacja zachowań wyborczych $w$ Polsce jako rezultat cywilizacyjnego rozdarcia kraju, [w:] Przestrzeń wyborcza Polski, red. M. Kowalski, Warszawa 2003, s. 17. 
Wyborczą. W oparciu o te dane przedstawiono wnioskowanie na podstawie historycznych wyników wyborów, trendów wyborczych obserwowanych w relacjach miasto-wieś oraz istniejących opracowań naukowych dotyczących przestrzennego zróżnicowania zachowań wyborczych w Polsce.

W analizach posłużono się metodami statystycznymi (do opisu i przedstawienia zjawisk związanych z zachowaniami wyborczymi) oraz kartograficznymi (w celu ukazania przestrzennego podziału elektoratów).

W badaniach uwzględniono zachowania wyborcze (frekwencję i wyniki wyborów) w 7 z 8 stałych obwodów głosowania (uwzględniono wszystkie otwarte obwody)(ryc. 1). Nie uwzględniono wyników głosowania w obwodzie 8 utworzonym na potrzeby użytkowników Domu Pomocy Społecznej w Przatówku. Wynika to $z$ jego niewielkiego zasięgu przestrzennego i potencjału demograficznego oraz konieczności zachowania czytelności map (por. J. Dzieciuchowicz, K. Dmochowska4).

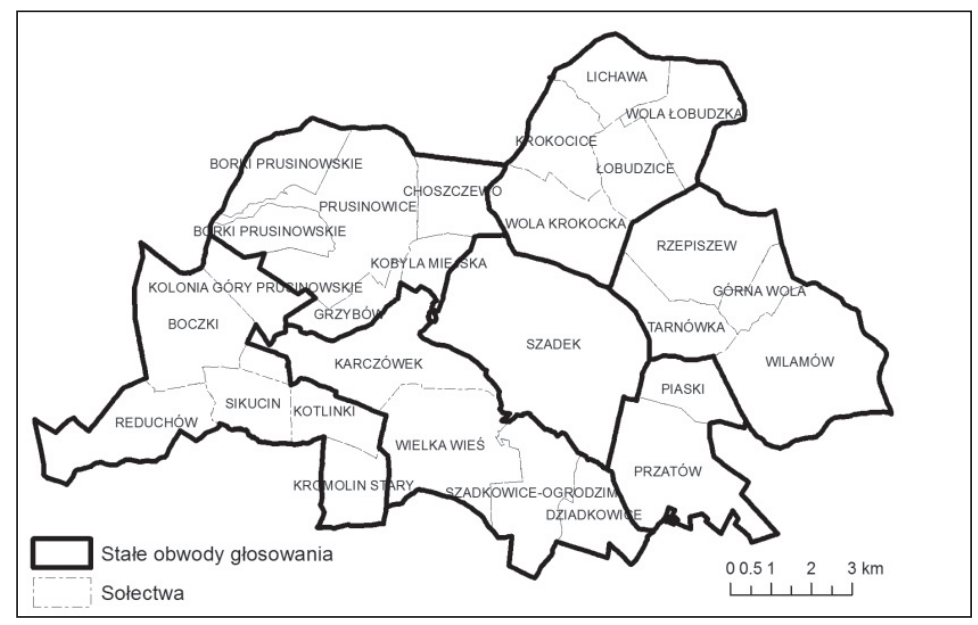

Ryc. 1. Stałe obwody głosowania w wyborach prezydenckich i parlamentarnych w gminie Szadek w 2015 r.

Źródło: opracowanie własne

Z uwagi na niewielki zakres przestrzenny badań próby wnioskowania mają ogólny charakter (brak w nich odniesień do bardziej szczegółowych charakterystyk wyborców i ich warunków życiowych w poszczególnych obwodach w porównaniu do badań wykonywanych dla większych jednostek osadniczych - por. Sobczyński $2000^{5}$ ).

${ }^{4}$ J. Dzieciuchowicz, K. Dmochowska, Plansza XIX a: Postawy wyborcze mieszkańców Łodzi: wybory samorzadowe w roku 2006, [w:] Atlas Miasta Łodzi. Suplement 1, Plansza XIXa, red. S. Liszewski, Wyd. Urząd Miasta Łodzi, Łódzkie Towarzystwo Naukowe, Łódź 2009.

${ }^{5}$ M. Sobczyński, Zróżnicowanie przestrzenne postaw politycznych mieszkańców Łodzi, Łódź 2000, s. 261-282. 


\section{WYBORY PREZYDENCKIE}

Pierwsza tura wyborów prezydenckich odbyła się 10 maja 2015 r. Frekwencja wyborcza w analizowanej gminie wyniosła 44,35\% i była najniższa spośród wszystkich gmin powiatu zduńskowolskiego (średnia dla całego powiatu wyniosła 49,19\%) i znacznie niższa od średnich: ogólnokrajowej (48,96\%) i wojewódzkiej $(49,72 \%)$. Próba wytłumaczenia niższej frekwencji w analizowanej gminie względem średniej krajowej jej położeniem w tzw. Kongresówce, która z reguły charakteryzuje się nieco niższą frekwencją (szczególnie na obszarach wiejskich), wydaje się być nieuzasadnione (co potwierdza wyższa od krajowej średnia frekwencja całego województwa łódzkiego - historycznie związanego z Królestwem Kongresowym). Dlatego należy domniemywać, iż kluczową w tym aspekcie jest relacja w zachowaniach wyborczych obserwowanych na osi miasto-wieś. Tradycyjnie w miastach obserwuje się wyższą frekwencję niż na obszarach wiejskich, a gmina Szadek jest gminą miejsko-wiejską, z dominującą (w ujęciu demograficznym) częścią wiejską?

W porównaniu do I tury poprzednich wyborów prezydenckich udział głosujących w ogóle uprawnionych do głosowania zmalał o ponad 6 pp. Druga tura, inaczej jak w poprzednich wyborach, zachęciła większą liczbę mieszkańców do oddania głosu. W efekcie frekwencja w ponownym głosowaniu wyniosła 50,72\% (w 2010 r. zanotowano spadek frekwencji o 0,21 pp.).

Zwykle wyższą frekwencję wyborczą obserwuje się w miastach. Zależność tę obserwuje się także w Szadku, gdzie w mieście frekwencja była wyższa niż na obszarach wiejskich, przy czym należy zauważyć, iż w grupie wsi występuje bardzo duże zróżnicowanie przestrzenne tego zjawiska. W I turze frekwencja w sołectwach położonych na wschód od Szadku była wyższa niż w mieście, podczas gdy w miejscowościach leżących na zachodnie gminy oraz na południowy i północny wschód od ośrodka miejskiego była bardzo niska. Frekwencja w ponownym głosowaniu najwyższa była w północno-wschodniej części gminy. Szczególnie daje się zauważyć zwiększenie frekwencji w obwodzie nr 4 (sołectwa: Krokocice, Lichawa, Łobudzice, Wola Krokocka i Wola Łobudzka), gdzie wzrosła aż o ponad 13 pp. Wspomniane duże zróżnicowanie może wynikać z faktu, iż obwody te są stosunkowo niewielkie i nieznaczne zwiększenie się bezwzględnej liczby osób oddających swój głos w wyborach znajduje dość duże odbicie w wartościach względnych.

${ }^{6}$ T. Zarycki, Polska przestrzeń wyborcza w perspektywie modelu centrum-peryferie, [w:] Przestrzeń wyborcza Polski, red. M. Kowalski, Warszawa 2003, s. 68.

${ }^{7}$ Ponad 72\% mieszkańców gminy stanowi ludność zamieszkująca obszary wiejskie. 


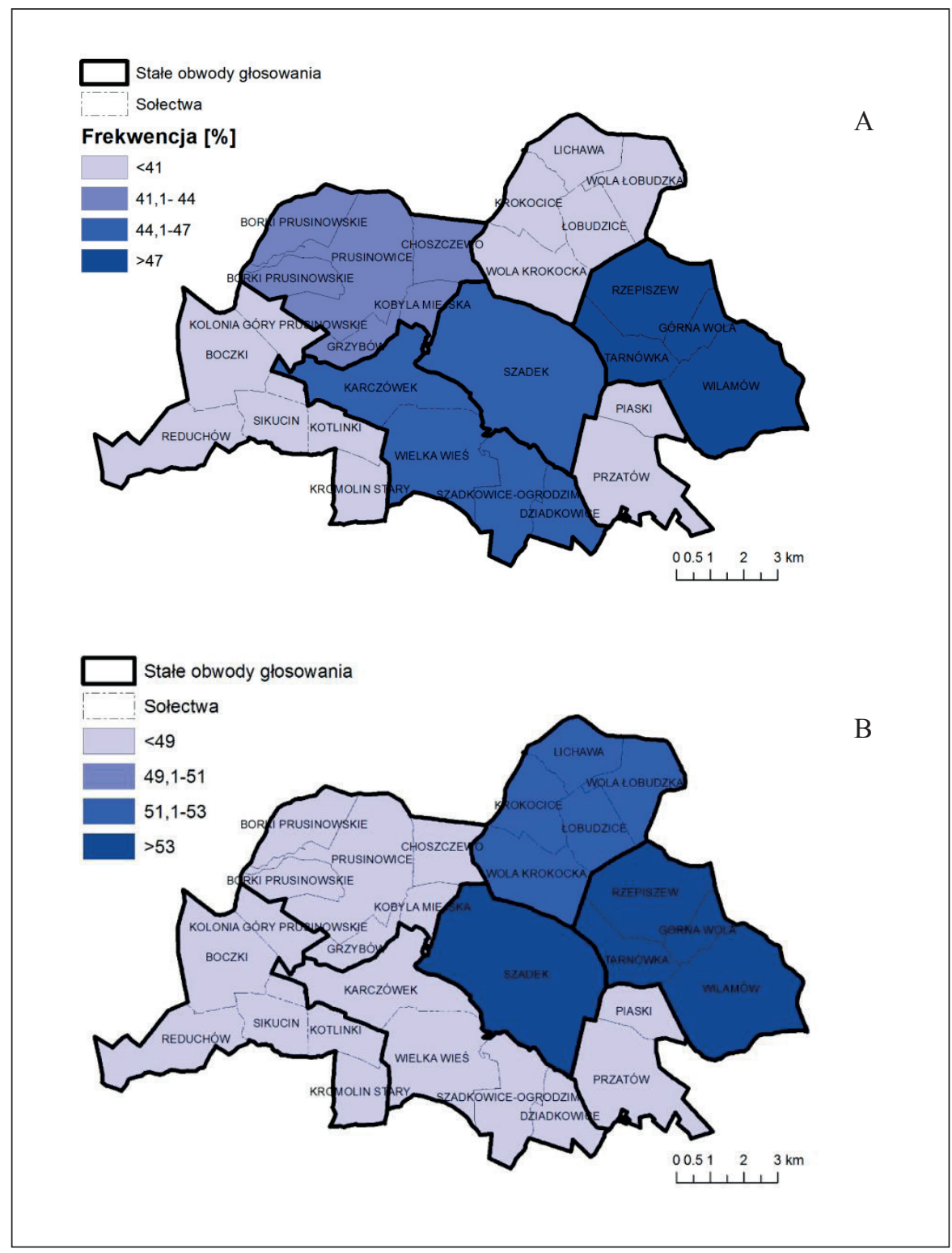

Ryc. 2. Frekwencja wyborcza w gminie Szadek w pierwszym głosowaniu (A) i głosowaniu powtórzonym (B) w wyborach prezydenckich w $2015 \mathrm{r}$. Źródło: opracowanie własne na podstawie danych PKW

Zjawisko wyższej frekwencji w polskich miastach obserwowane jest od wielu lat. Źródeł takiego stanu rzeczy upatruje się w wyższej świadomości społecznej i politycznej miast, często uwarunkowanej poziomem wykształcenia 
i zaangażowaniem w sprawy kraju ${ }^{8}$. Nie bez znaczenia we wspomnianym zróżnicowaniu w ujęciu miasto-wieś wydają się być także czynniki demograficzne (struktura wiekowa) oraz problem dostępności lokali wyborczych (na obszarach wiejskich, aby oddać głos na ogół trzeba pokonać znacznie większe odległości, co może stanowić istotną barierę dla niektórych wyborców).

W wyborach prezydenckich w 2015 r. startowało 11 kandydatów. Ich programy mniej lub bardziej wpisywały się w schemat podziału polskiej sceny politycznej zaprezentowanej we wprowadzeniu.

Tablica 1. Wyniki pierwszego głosowania w wyborach prezydenckich w Polsce i gminie Szadek w 2015 r.

\begin{tabular}{|c|c|c|c|c|}
\hline \multirow{2}{*}{$\begin{array}{c}\text { Nazwiska } \\
\text { kandydatów }\end{array}$} & \multicolumn{4}{|c|}{ Poparcie [w \%] } \\
\hline & $\begin{array}{c}\text { Szadek - obszary } \\
\text { wiejskie }\end{array}$ & Szadek - miasto & Gmina Szadek & Polska \\
\hline Braun & 0,59 & 0,91 & 0,75 & 0,83 \\
\hline Duda & 43,42 & 38,49 & 41,97 & 34,76 \\
\hline Jarubas & 3,78 & 1,17 & 3,00 & 1,60 \\
\hline Komorowski & 25,31 & 31,21 & 27,03 & 33,77 \\
\hline Korwin-Mikke & 2,08 & 1,95 & 2,03 & 3,26 \\
\hline Kowalski & 0,21 & 0,39 & 0,34 & 0,52 \\
\hline Kukiz & 20,25 & 21,33 & 20,42 & 20,80 \\
\hline Ogórek & 2,66 & 2,21 & 2,59 & 2,38 \\
\hline Palikot & 0,91 & 1,04 & 0,94 & 1,42 \\
\hline Tanajno & 0,32 & 0,39 & 0,34 & 0,20 \\
\hline Wilk & 0,48 & 0,91 & 0,60 & 0,46 \\
\hline
\end{tabular}

Źródło: opracowanie własne na podstawie danych Państwowej Komisji Wyborczej.

Wyborcy zamieszkujący gminę Szadek, podobnie jak w całej Polsce, w I turze poparli w głównej mierze Andrzeja Dudę, Bronisława Komorowskiego i Pawła Kukiza (tabl. 1 i ryc. 3). Zdecydowane zwycięstwo kandydata prawicowego (niewiodącego w sondażach przedwyborczych, w przeciwieństwie do swojego głównego konkurenta) w gminie Szadek może wpisywać się w trend obserwowany w gminach dawnej Kongresówki, który polega na stosunkowo niskim odsetku poparcia dla najsilniejszych (w tym przypadku teoretycznie) ugrupowań ${ }^{9}$ (lub kandydatów przez nich popieranych).

${ }^{8}$ P. Krzemiński, Zachowania wyborcze $w$ wyborach parlamentarnych i prezydenckich $w$ Polsce w latach 2005-2007 - wzory przestrzennych zróżnicowań, „Przegląd Geograficzny”, t. 81, z. 2, Warszawa 2009, s. 264-266.

9 J. Bartkowski, Regionalne zróżnicowanie niektórych wymiarów kapitału społecznego w Polsce, „Przegląd Socjologiczny”, t. 57, z. 1, Łódź 2008, s. 74. 
$\mathrm{Na}$ obszarze analizowanej gminy dostrzegalne są pewne różnice w poparciu kandydatów w relacji miasto-wieś. Największe i najciekawsze z politologicznego punktu widzenia dotyczyły A. Dudy (względne poparcie wyższe na obszarach wiejskich o ok. 5 pp.), B. Komorowskiego (wyższe w mieście o ok 6 pp.) i A. Jarubasa (wyższe na obszarach wiejskich o ok 2,5 pp.).

Uwidoczniający się w latach 90-tych i na początku XXI w. geograficzny podział elektoratów zdaje się być w znacznym stopniu utrzymany. Większe poparcie dla kandydata prawicowego (A. Dudy) na obszarach wiejskich dawnej „Kongresówki" (co jest szczególnie widoczne w województwie łódzkim) ${ }^{10} \mathrm{~W}$ porównaniu do miast (nawet małych, jakim jest Szadek) jest jednym z tego przejawów.

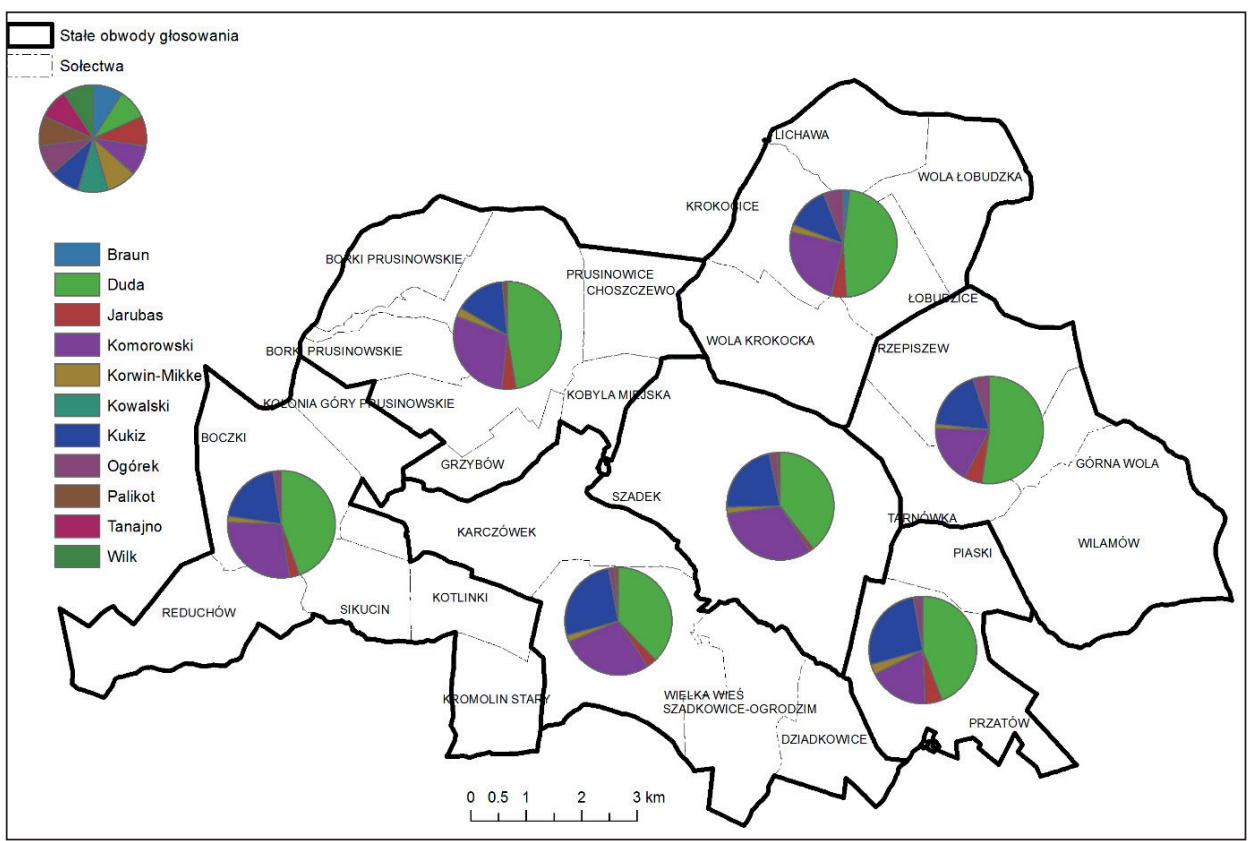

Ryc. 3. Wyniki pierwszego głosowania w wyborach prezydenckich w obwodach na obszarze gminy Szadek w $2015 \mathrm{r}$.

Źródło: opracowanie własne na podstawie danych PKW

Bardzo często dobrze widoczną różnicą pomiędzy preferencjami wyborczymi mieszkańców miast i wsi są wyniki wyborcze przedstawicieli partii ludowych. Nie inaczej było w wyborach prezydenckich w 2015 r., kiedy to kandydat PSL w gminie Szadek uzyskał ponad trzykrotnie lepszy rezultat na jej obszarach wiejskich. Niemniej jednak zauważalne jest powolne zmniejszanie się wspomnianej różnicy, na co ma wpływ uszczuplanie się elektoratu partii ludowych (zmniejszanie się

${ }^{10}$ M. Kowalski, Polaryzacja zachowań..., s. 17. 
udziału mieszkańców utrzymujących się z rolnictwa) oraz jego odpływ w kierunku partii prawicowych (PiS). Należy to utożsamiać z coraz większym znaczeniem osi wartości względem osi interesów w podejmowaniu decyzji politycznych przez niegdyś tradycyjnie głosujących na partie ludowe ${ }^{11}$.

W relacjach pomiędzy miastem a wsią nie mniej ważną rolę odgrywa także oś interesów. Potwierdza to niższe poparcie B. Komorowskiego na wsiach i większe w miastach, przy czym zależność ta w skali ogólnopolskiej jest jeszcze większa niż w lokalnej skali Szadku. Analizując wyniki wyborów, można wysnuć tezę, iż (oczywiście poza pewnymi wyjątkami) im większe miasto, tym większa różnica w poparciu na korzyść kandydata liberalnego.

Wydaje się jednak, że skala badań i brak ich pogłębienia o informacje dotyczące wyborców (chociażby takiego, jakie stosuje się w badaniach exit polls) uniemożliwia próbę interpretacji wyników w podziale na poszczególne obwody głosowania.

II tura wyborów, która odbyła się 24 maja 2015 r., odzwierciedliła w znacznym stopniu charakter tradycyjnego, przedstawionego wcześniej, podziału elektoratu. W gminie Szadek największym poparciem cieszył się Andrzej Duda, uzyskując 63,21\% głosów (zdobywając ponad 50\% głosów w każdym z obwodów), przy $36,79 \%$ oddanych na Bronisława Komorowskiego. Różnica w wynikach głosowania (ryc. 4) była największa na obszarach wiejskich.

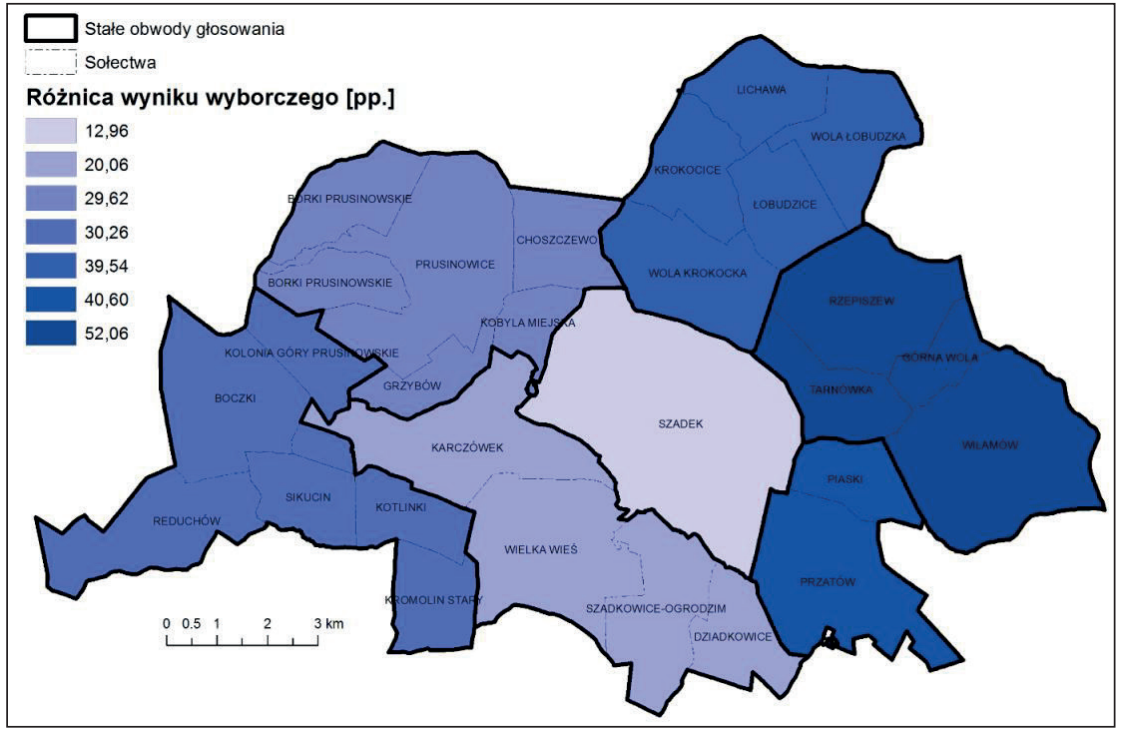

Ryc. 4. Różnica wyniku wyborczego kandydatów w wyborach prezydenckich w ponownym głosowaniu (II tura) w obwodach na obszarze gminy Szadek w 2015 r. Źródło: opracowanie własne na podstawie danych PKW

11 J. Bański, M. Kowalski, M. Mazur, Zachowania wyborcze mieszkańców polskiej wsi, „Przegląd Geograficzny”, t. 81, z. 4, Warszawa 2009, s. 488-499. 


\section{WYBORY PARLAMENTARNE}

Wybory parlamentarne w 2015 r. odbyły się 25 października. Frekwencja ${ }^{12}$ była nieco wyższa niż w poprzednich wyborach (w $2011 \mathrm{r}$.) i wyniosła: w skali krajowej $(50,92 \%)$, regionalnej $(51,63 \%)$ oraz lokalnej w powiecie poddębickim $(49,72 \%)$ i gminie Szadek (44,93\%). Najwyższą frekwencją w analizowanej gminie charakteryzowały się obszary miejskie $(49,15 \%$ przy $43,16 \%$ na wsiach), co wydaje się być potwierdzeniem tez przedstawionych wcześniej - dotyczących mniejszego zaangażowania politycznego mieszkańców wsi.

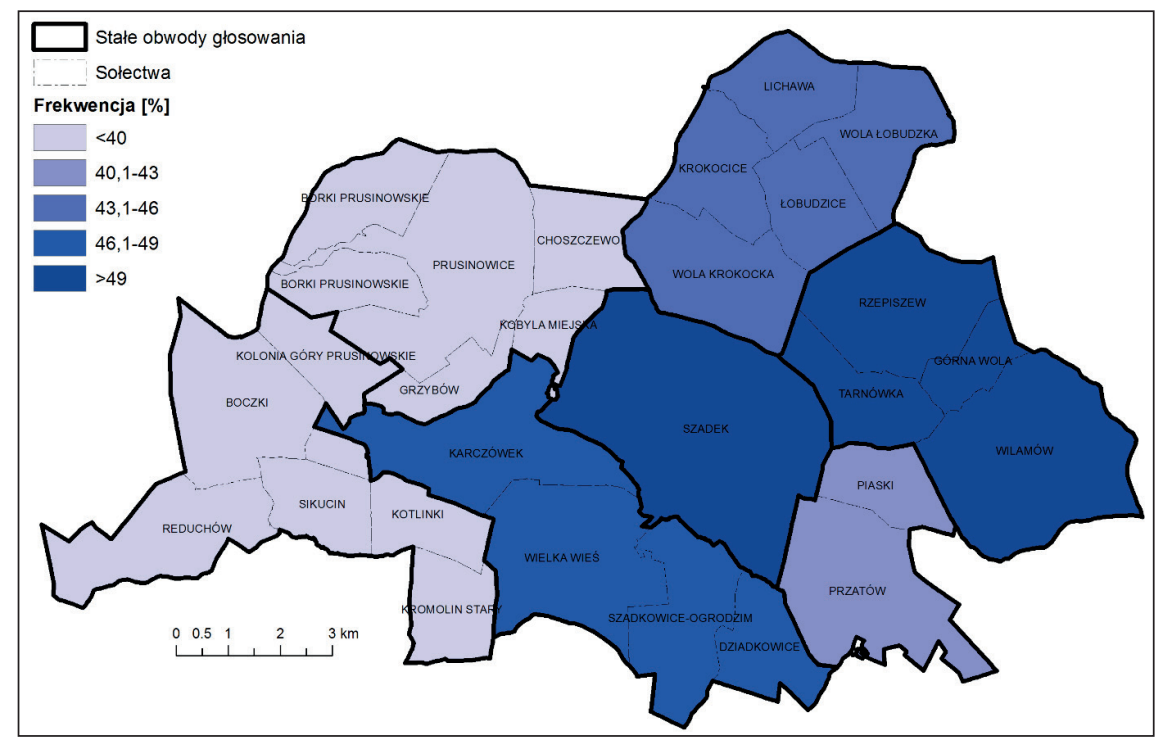

Ryc. 5. Frekwencja w wyborach do sejmu w gminie Szadek w 2015 r. Źródło: opracowanie własne na podstawie danych PKW

Na obszarze gminy Szadek można było głosować na jedną z 11 list zgłoszonych w wyborach do izby niższej parlamentu. Wyniki wyborów do sejmu w stosunkowo niewielkim stopniu odzwierciedliły sympatie wyborcze mieszkańców gminy uzewnętrznione w majowych wyborach prezydenckich. Zwycięską okazała się być partia, z poparciem której na urząd prezydenta asygnowany został Andrzej Duda - Prawo i Sprawiedliwość (PiS). Poparcie tej partii (Wykres 1) było porównywalne z poparciem, jakie otrzymał asygnowany przez nią kandydat na prezydenta (różnica wyniku z I tury wyborów prezydenckich a wyborami

12 Przedstawione wartości opisują frekwencję w wyborach do sejmu, która generalnie charakteryzowała się nieco większym zainteresowaniem, niż odbywające się w tym samym czasie i miejscu wybory do senatu. 
do sejmu wyniosła 1,41 pp. na korzyść A. Dudy). Niemniej jednak w okresie pomiędzy wyborami nastąpiły poważne przesunięcia w obrębie elektoratów wzdłuż linii podziału liberałowie-ludowcy na korzyść PSL-u. Listy Polskiego Stronnictwa Ludowego przyciągnęły znacznie więcej wyborców niż kandydat tej partii w wyborach prezydenckich (różnica wynosi ponad 18 pp.). Z kolei na listy liberalnej Platformy Obywatelskiej oddano aż o ponad $13 \mathrm{pp}$. mniej głosów niż na Bronisława Komorowskiego popieranego przez tę partię w wyborach prezydenckich. Istotne różnice poparcia zaobserwowano także $\mathrm{w}$ przypadku listy ruchu Kukiz'15, który uzyskał aż o 11,5 pp. mniejsze poparcie niż Paweł Kukiz w wyborach prezydenckich. Trudno jednoznacznie wskazać, na ile wspomniane przesunięcie wynika ze zmiany orientacji politycznej, a na ile z samej charyzmy i zaufania do kandydatów na urząd prezydenta. O wiele lepsze wyniki wyborcze, od swoich przedstawicieli w wyborach prezydenckich, w wyborach do sejmu uzyskała z kolei lista wyborcza Zjednoczonej Lewicy (ZL) (w wyborach parlamentarnych Zjednoczona Lewica uzyskała wynik ponad dwukrotnie wyższy niż popierana przez środowiska lewicowe Małgorzata Ogórek). Nowa partia - Nowoczesna, choć uzyskała sukces wyborczy w skali kraju, nie cieszyła się dużym poparciem mieszkańców gminy Szadek, podobnie jak listy zgłoszone przez pozostałe komitety wyborcze, które w skali ogólnopolskiej nie uzyskały poparcia umożliwiającego im posiadanie reprezentacji w sejmie VIII kadencji.

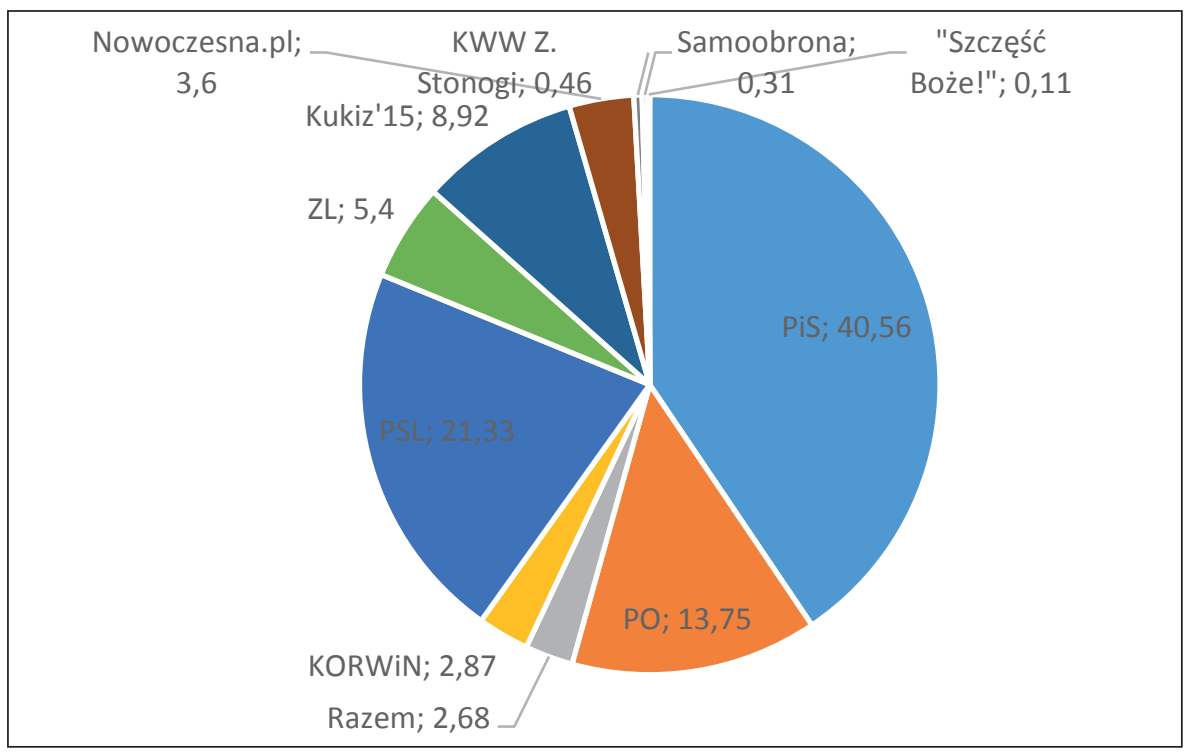

Wykres 1. Wyniki wyborów do sejmu w 2015 r. w gminie Szadek [\%] Źródło: opracowanie własne na podstawie danych PKW 


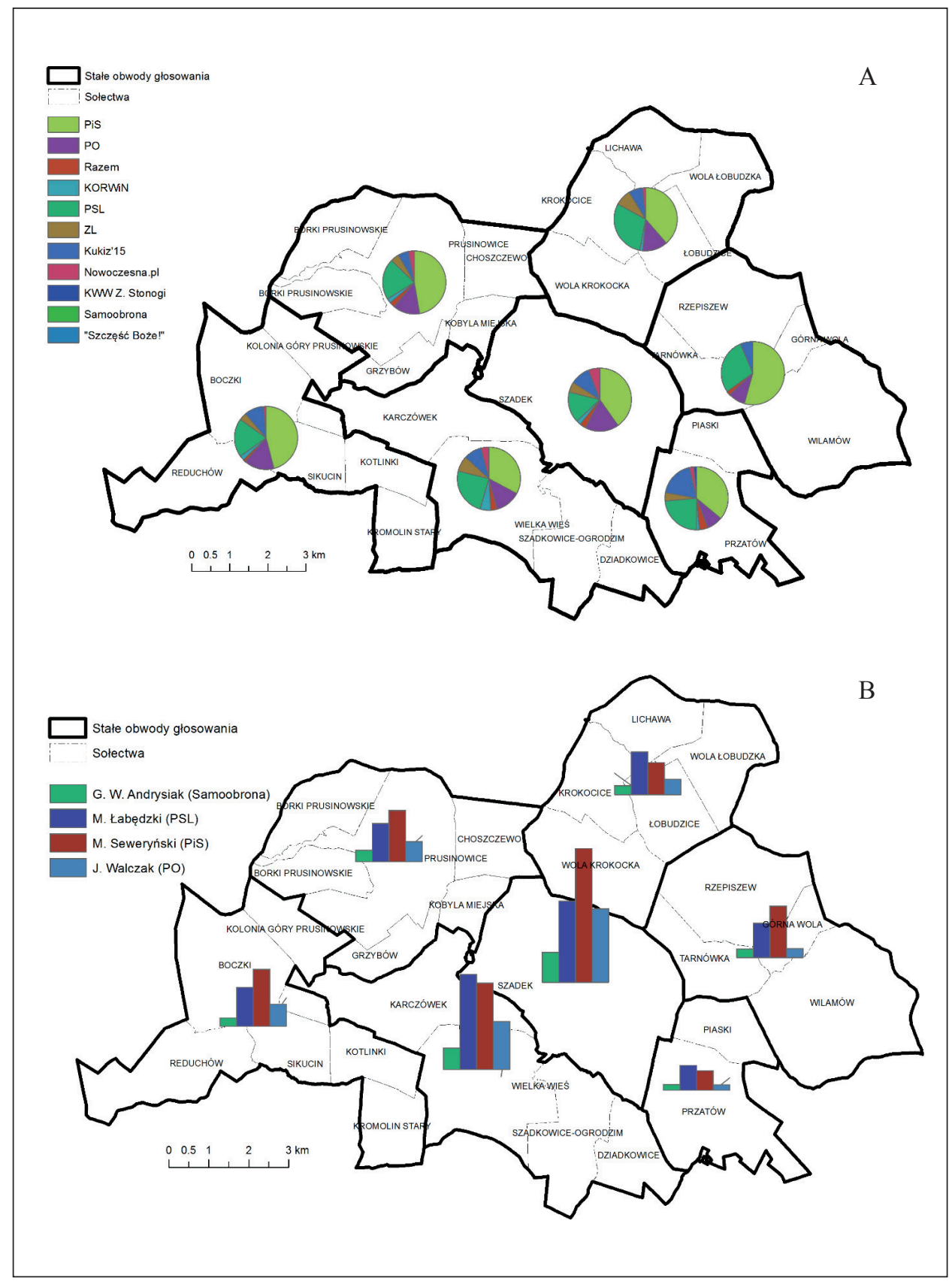

Ryc. 6. Wyniki wyborów do sejmu (A) i senatu RP (B) w podziale na stałe obwody w gminie Szadek w 2015 r.

Źródło: opracowanie własne na podstawie danych PKW 
W analizowanej gminie zarówno na obszarach wiejskich, jak i w mieście największą liczbę głosów zdobyły partie prawicowe (ryc. 6). Niemniej jednak po raz kolejny daje się zauważyć wyraźną różnicę wyników wyborczych w miastach i na obszarach wiejskich. Generalnie w miastach obserwuje się zmniejszenie udziału partii prawicowych (PiS) na korzyść partii liberalnych (PO i Nowoczesna). W przypadku wyborów parlamentarnych wciąż dostrzegalna jest oś interesów dzieląca elektorat PSL (ludowców) i partii liberalnych.

Wyborcy PiS z terenu gminy Szadek najchętniej oddawali swoje głosy na Piotra Polaka startującego z pozycji nr 6. Oddano na niego ponad 33,3\% głosów przekazanych na listę PiS i 13,52\% ogółu głosów z gminy Szadek. Nieco rzadziej głosowano na Grzegorza Schreibera (dwójkę na liście) 21,53\% głosów oddanych na listę i Witolda Waszczykowskiego (16,62\%). Przedstawione wyniki wyborcze świadczą o dużej rozpoznawalności i zaufaniu do Polaka, tym bardziej, iż z badań przeprowadzonych przez Peszyńskiego (2011) wynika, iż elektorat PiS najczęściej głosuje na kandydatów z pierwszej pozycji na liście (z badań wynika również, że decydując się na oddanie głosu, wyborcy PiS-u najczęściej kierują się poparciem partii, a nie konkretnego kandydata) ${ }^{13}$.

Osoby, które oddawały swój głos na kandydata z listy PO najczęściej wybierały (ponad 60\%) startującego z pierwszego miejsca na liście Cezarego Tomczyka. Podobnie w pozostałych partiach z reguły najwięcej głosów otrzymywali kandydaci na pierwszych miejscach swoich list wyborczych (Rzymkowski - Kukiz'15, Olejniczak - ZL, Utecht - KORWiN). Wyjątkiem jest PSL, gdzie najwięcej głosów otrzymał startujący z miejsca 11 na liście - Artur Lawniczak (zdobył ponad 72\% głosów oddanych na listę i osiągnął najlepszy wynik w gminie spośród wszystkich kandydatów startujących do sejmu - 15,4\%).

W wyborach do senatu z okręgu nr 25 startowało 4 kandydatów. Najwięcej głosów zdobył Michał Seweryński (40,15\% ogółu głosów) reprezentujący PiS, a na kolejnych miejscach uplasowali się: Marcin Łabędziki (32,94\%) (PSL), Jacek Walczak (17,89\%) (PO) i Grzegorz Witold Andrysiak (9,02\%) (Samoobrona). W wyborach do senatu dało się zauważyć większe dysproporcje pomiędzy głosami oddanymi na ugrupowania ludowe na obszarach wiejskich i w miastach. W trzech okręgach (4, 6 i 7) okalających Szadek od południa i północnego wschodu najwięcej głosów zebrał kandydat PSL, w pozostałych zwyciężył kandydat PiS, przy czym najsłabszy względny wynik osiągnął w okręgu miejskim, w którym znacznym poparciem cieszyli się Łabędzki $(25,49 \%)$ i Walczak $(23,14 \%)$.

${ }^{13}$ W. Peszyński, Kandydat czy partia? W poszukiwaniu determinant zachowań wyborczych elektoratu, [w:] Preferencje polityczne. Postawy-identyfikacje-zachowania, red. A. Turska-Kawa, Z. Widera, W. Wojtasik, Katowice 2011, s. 234-238. 


\section{PODSUMOWANIE}

Zachowania wyborcze mieszkańców gminy Szadek różnicują się w zależności od wielkości jednostki osadniczej, w której zamieszkują. Dotyczy to zarówno frekwencji, jak i poparcia. Im większa jednostka osadnicza (Szadek), tym z reguły większa aktywność wyborców. Wydaje się, iż w tym kontekście nie bez znaczenia jest dostępność mieszkańców do lokali wyborczych.

Na obszarze gminy obserwuje się tradycyjny podział elektoratów - na elektorat wiejski i miejski. W wyborach z 2015 r. daje się zauważyć pewne trendy dotyczące ich wewnętrznych przemian. Pierwszy z nich (miejski) w dalszym ciągu w dużej mierze opiera się na osi interesów (na co wskazuje większy udział głosów oddanych na kandydatów i listy partii liberalnych względem ludowych, przy czym względem innych małych miast tego regionu różnica w Szadku jest stosunkowo niewielka), jednak obserwuje się większe znaczenie osi wartości, co zostało uzewnętrznione poprzez dużą liczbę głosów oddanych na prawicę (co zdaje się wpisywać Szadek do typowych małych miast dawnej kongresówki). Wspomniane poparcie ma charakter w zasadzie jednokierunkowy - prawicowy.

Charakterystyczne dla elektoratu wiejskiego jest kierowanie się osią interesów co przejawia się w dużym udziale głosów oddanych na PSL (na obszarach wiejskich gminy Szadek wspomniana partia uzyskała drugi, za PiS, wynik wyborczy). Niemniej jednak sukces wyborczy, zwycięstwo we wszystkich okręgach PiS-u, wpisuje się $\mathrm{w}$ trend obserwowany na terenach wiejskich dawnego Królestwa Kongresowego, gdzie partie prawicowe cieszą się względnie dużym i rosnącym poparciem.

W rezultacie wyborów o charakterze ogólnopolskim w 2015 r. prezydentem Rzeczpospolitej Polskiej został Andrzej Duda, zaś parlamentarzystami z badanego okręgu wyborczego zostali:

posłowie: Witold Waszczykowski (PiS), Grzegorz Schreiber (PiS), Beata Mateusiak-Pielucha (PiS), Tadeusz Woźniak (PiS), Marek Matuszewski (PiS), Piotr Polak (PiS), Łukasz Rzepecki (PiS), Cezary Tomczyk (PO), Agnieszka Hanajczyk (PO), Artur Dunin (PO), Paweł Bejda (PSL), Tomasz Rzymkowski (Kukiz'15); senator: Michał Seweryński (PiS).

\section{Bibliografia}

Bański J., Kowalski M., Mazur M., Zachowania wyborcze mieszkańców polskiej wsi, „Przegląd Geograficzny”, t. 81, z. 4, Warszawa 2009.

Bartkowski J., Regionalne zróżnicowanie niektórych wymiarów kapitału społecznego w Polsce, „Przegląd Socjologiczny”, t. 57, z. 1, Łódź 2008.

Barwiński M., Leśniewska K., The comparison of the contemporary situation of national minorities in Poland and Lithuania, „Geografijos metraštis”, t. 46, s. 56-58, Wilno 2013. 
Dzieciuchowicz J., Dmochowska K., Plansza XIX a: Postawy wyborcze mieszkańców Łodzi: wybory samorzadowe w roku 2006, [w:] Atlas Miasta Łodzi. Suplement 1, Plansza $X I X a$, red. S. Liszewski, Urząd Miasta Łodzi, Łódzkie Towarzystwo Naukowe, Łódź 2009.

Kowalski M., Polaryzacja zachowań wyborczych $w$ Polsce jako rezultat cywilizacyjnego rozdarcia kraju, [w:] Przestrzeń wyborcza Polski, red. M. Kowalski, Warszawa 2003.

Krzemiński P., Zachowania wyborcze $w$ wyborach parlamentarnych $i$ prezydenckich w Polsce w latach 2005-2007 - wzory przestrzennych zróżnicowań, „Przegląd Geograficzny", t. 81, z. 2, Warszawa 2009.

Państwowa Komisja Wyborcza, www.pkw.gov.pl

Peszyński W., Kandydat czy partia? W poszukiwaniu determinant zachowań wyborczych elektoratu, [w:] Preferencje polityczne. Postawy - identyfikacje - zachowania, red. A. Turska-Kawa, Z. Widera, W. Wojtasik, Katowice 2011.

Sobczyński M., Zróżnicowanie przestrzenne postaw politycznych mieszkańców Łodzi, Łódź 2000.

Zarycki T., Polska przestrzeń wyborcza w perspektywie modelu centrum-peryferie, [w:] Przestrzeń wyborcza Polski, red. M. Kowalski, Warszawa 2003.

Zarycki T., Kulturowe-polityczne uwarunkowania modernizacji Polski wschodniej i zachodniej. Geografia polityczna i jej interpretacje, [w:] Historyczno-kulturowe uwarunkowania rozwoju: Polska i Ukraina, red. G. Gorzelak, A. Tucholska, Warszawa 2008.

[Wpłynęło: marzec; poprawiono: czerwiec 2016 r.]

\section{SPATIAL VARIATION IN ELECTORAL BEHAVIOUR OF SZADEK MUNICIPALITY RESIDENTS IN 2015 PRESIDENTIAL AND PARLIAMENTARY ELECTIONS}

\section{Summary}

The article presents the voting behaviour in the municipality of Szadek in the elections of 2015. The investigation of the electoral behaviour comprises the turnout and voting results in each of the electoral districts, and a synthetic city-countryside comparison. The article is an attempt to explain the variation in voter turnout and transfers within the electorate.

Keywords: Szadek, presidential elections, parliamentary elections, electoral behaviour. 